\title{
An Analysis of English Translation of Zigong Lantern Festival Introduction on Webpage
}

\author{
Wu Chunrong (Corresponding author) \\ School of Foreign Languages, Sichuan University of Science \& Engineering \\ Zigong, Sichuan Province, China
}

Tel: 86-0813-5505883; 13890009729 E-mail: 363493649@qq.com

Li Zenghui

School of Foreign Languages, Sichuan University of Science \& Enginnering

Zigong, Sichuan Province, China

Tel: 86-0813-5505883; 13890009729 E-mail: 799069024@qq.com

Received: May 19, 2014 Accepted: June 20, 2015 Published: June 25, 2015

doi:10.5296/jsss.v2i2.7633 URL: http://dx.doi.org/10.5296/jsss.v2i2.7633

\begin{abstract}
This essay analyzes Zigong Lantern Festival's English introduction on webpage under the framework of Peter Newmark who divides texts into expressive text, informative text and vocative text and holds that different text types correspond to different translation methods. Through the analysis of the source text and target text of Zigong Lantern Festival introduction, the author finds that during the process of translating, adjustments to the sentences' order and addition of information were well-made by the translator with specific and typical analysis offered. In addition, for some redundant information produced in the process of adding information, the essay analyzes it and offers suggestions for future improvement, hoping to promote the economic development of Zigong in Sichuan province of China.
\end{abstract}

Keywords: Zigong Lantern Festival introduction, Newmark's translation theory, Text typology 


\section{Introduction}

Zigong lantern festival stands out from all lantern shows (Note 1) and wins a good reputation. Today, Zigong Lantern Festival is walking outside of China; website promotion apparently becomes an important window for people to enjoy the sight of lanterns, learn about the profound Chinese culture and to seek to trade so as to bring about economic development. However, there is lack of researches on C-E translation of Zigong Lantern Festival based on sound theoretical foundations.

The concept of text typology was first proposed by Newmark who categorized text types into three types, i.e. expressive text, informative text and vocative text. In order to solve problems of different text types' translation, he presents two dominant translation approaches, namely, semantic translation and communicative translation (Newmark, 2001: 38). Semantic translation emphasizes the thinking process of the author and represents the original meanings of the source text. It can preserve the characteristics and expression patterns of the source language, forcing readers to follow the thinking pattern of the author. While communicative translation indicates that the influence of translation on target readers should be identical to the effect of original text on source readers. This translation strategy allows translator to reorganize sentences with classical phrases in the target language to make his translation accessible to the target readers.

Based on Newmark's theoretical framework, semantic translation is mainly used for expressive text, while communicative translation is adopted for informative text and vocative text. Zigong Lantern Festival introduction owns the characteristics of informative text and vocative text. Adopting the guiding translation principle, this essay aims to explore how the method is applied and what effect it would have on target readers.

\section{Zigong Lantern Festival's Status and Development}

Zigong lantern festival assembles the mien of Chinese colorful lantern culture and wins the good name of "The First Lantern Show in the World", thus making Zigong, the national historical and cultural city famous as the "Age-old Salt Capital", "Hometown of Dinosaurs" and "Lantern City of South China" both at home and abroad (Note 2).

Zigong Lantern Festival is intrinsic to the Lantern City of South China. Taking shape in the period of Ming and Qing, it has gradually evolved into a large folk culture activity which has a relatively fixed meaning and is held in a particular time. With the development and changes of society, Zigong Lantern Festival became more exquisite and skilled under the nurture of national culture. In 1964, Zigong people's government hosted the first lantern festival after the founding of new China. From then on, the scale of the lantern festival became larger and the craft more refined. Lanterns began to be exhibited by groups instead by individuals and the layout was no longer planar but stereotypical. Since 1988, Zigong Lantern Festival has been held in all provincial capitals of China and over 200 times in more than 40 countries, enjoying a very good reputation.

Nowadays, thanks to the combination of traditional culture and modern science and technology, Zigong Lantern Festival has reached up to a new level in designing, originality, 
producing process, energy-saving and environmental protection. In Zigong, lantern fabrication, lantern show and Lantern Festival trade fair have become a new industry and urban economic growth point. The festival has become a big holiday of culture, science and technology and tourism, a big market full of traders and investment and a big window of promoting unity and cooperation, opening and development and international communication.

\section{Text Typology and Newmark's Translation Theory}

\subsection{Text Typology}

From Newmark's view, the work of translation is a translation of the text; the text cannot be put aside when we do research on translation. Thus, Newmark divided all texts into three main types, i.e. expressive text, informative text and vocative text (Newmark, 2001: 15). In order to solve problems of translation of different text types, he proposed two dominant translation approaches, namely, semantic translation and communicative translation (Newmark, 2001: 38).

\subsection{Newmark's Translation Theory}

According to Peter Newmark, communicative translation attempts to produce on its readers an effect as close as possible to what is obtained on the readers of the original. It is target-language-orientated and focuses on transference of information. This translation strategy allows translator to reorganize sentences to make his translation accessible to the target readers. While semantic translation attempts to render the exact contextual meaning of the original. In this case, translator makes little interference with the harmony of the source text (Newmark, 2001: 39).

In theory, there are wide differences between the two methods. One basic difference between the two methods is that the communicative must emphasize the effect rather than the content of the message, and it responds to the representational and vocative functions of language, whereas semantic translation attempts to recreate the precise flavor and tone of the original and it relates to the expressive function of language.

Generally, a communicative translation is likely to be smoother, simpler, clearer, more direct, more conventional, conforming to a particular register of language, tending to undertranslate, i.e. to use more generic, hold-all terms in difficult passages. A semantic translation tends to be more complex, more awkward, more detailed, more concentrated, and pursues the thought-processes rather than the intention of the transmitter. It tends to overtranslate, to be more specific than the original, to include more meanings in its search for one nuance of meaning. Besides, in terms of text typology, semantic translation is usually applied to expressive text and communicative translation is usually applied to informative and vocative text.

Communicative and semantic translation may well coincide, there is no single one communicative nor one semantic method of translating a text, these are in fact widely overlapping bands of methods. A translation can be more or less semantic, more or less 
communicative (Newmark, 2001: 40).

\section{The Application of Newmark's Translation Theory in Translating Zigong Lantern Festival Introduction}

\subsection{The Feasibility of Applying Communicative Translation to the Text}

In Peter Newmark's categorization, the core thought that lies in the expressive text is the communication of ideas and feelings. The unique language form of author and the content should be of equal importance. Therefore, this type of text emphasizes the authority of the original authors, and is not going to consider readers' responses. Typical expressive text includes: serious literary works, lyric poetries, novels, short stories, plays and so on; Authoritative statements, including political speeches or documents of the national political figures, various regulatory and legal literature as well as scientific, philosophical and academic compositions written by the recognized authority; Autobiography, essays and personal letters.

Informative text emphasizes the authenticity and information beyond languages. Typical informative text can cover any area of knowledge, including science, technology, commerce, industry, economy and so on. Its expressive forms include textbooks, articles on newspapers and magazines, technical reports, minutes of the meeting, and so on. Authenticity of the content is the core of informative text and the author's language is secondary. Therefore, when translating informative text, the principle of truthfulness should be followed first. When dealing with the text, the translator may not be constrained to the original, but with the reader's language level as a standard to pursue a goal of smoothness so as to the translation can be easy to understand. Besides, an amendment to the original text can be made if necessary. Compared with expressive text, the translator has more freedom, for instance, when the original expression is vague, confusing or imprecise, translators are responsible for modifying for the sake of being conscientious for the target language readers. Based on this, when translating informative text-dominated foreign exchange materials, the translator can be free from the shackles of original structure, reorganize the original narrating sequence, and substantiate the original information with a free style.

Vocative text stresses an idea of reader-centered, aimed at calling on readers to act, to think, to feel. Notices, product specifications, brochures, advertisements all fall into this category. When dealing with vocative text, target readers should be considered first and the translator can take full advantages of the use of the target language, instead of rigidly adhering to the way of the original expression, to make the language of translation produce the same effect as the original language. When the original expression is vague, confusing or imprecise, the translator is also responsible for modification.

Based on the explanation of the types of texts for translation, the translation of Zigong Lantern Festival Introduction, as a brief description of an exceptional product and unique culture, owns the characteristics of informative text and vocative text because it not only describes to all those who will browse this introduction both its history, development and advancement and profound Chinese culture behind it; but also appeals to the visitors, such as 
merchants, to the website to choose Zigong Lantern Festival to cooperate with their country or city and let Zigong lanterns, brilliant and splendid, to illuminate their world.

Therefore, combined with the previous introduction that Newmark thinks different text types correspond to different translation methods and informative text and vocative text should adopt communicative translation theory, this thesis mainly selects communicative translation approach to analyze the translation text.

\subsection{The Application of Communicative Translation}

Newmark assumed that whilst a semantic translation is always inferior to its original, since it involves loss of meaning, a communicative translation may be better, since it may gain in force and clarity what it loses in semantic content. In communicative translation, the translator is trying in his own language to write a little better than the original, unless he is reproducing the well-established formulate of notices or correspondence. He assumed that in communicative translation one has the right to correct or improve the logic; to replace clumsiness with elegance, or at least functional, syntactic structures; to remove obscurities; to eliminate repetition and tautology; to exclude the less likely interpretations of an ambiguity and to modify and clarify jargon. Further, one has the right to correct mistakes of fact and slips (Newmark, 2001: 42). (All such corrections and improvements are usually inadmissible in semantic translation.)

This section investigates translation of Zigong Lantern Festival introduction mainly from the angle of adjustment of sentence order and supplement of information made by the translator based on Newmark's assumption.

\subsubsection{The Adjustment of Sentence Order}

There are wide differences between English and Chinese. Wang Haixia believes that English emphasizes hypotaxis. Its sentence structure subjects to constraints of syntax and the organization of discourse focus on explicit coherence. In contrast, Chinese language focuses on parataxis. It is always loosely organized and its grammatical meaning and logic is often hidden between the lines (Wang Haixia, 2010). Yan Desheng has ever pointed out that when researching or organizing translation, one's focus should fall on logic (Yan Desheng, 1999). Considering the differences in logical thinking and linguistic structure between English and Chinese, one should first have a macro-level system design and then use various techniques for microscopic processing at the sentence level when translating.

The translator realized this issue and dealt carefully with the translation of Zigong Lantern Festival introduction. Here is an example:

The source text:

“进入九十年代以来, 自贡灯会作为中华民族的文化使者, 更大步地走出国门, ......将中 国灯文化的奇光异彩传播到海外各地。……自贡灯会向着经贸型、集约化、国际化方向 发展, 取得了良好的社会效益和经济效益。

在自贡, 制灯、展灯、举办灯会经贸交易会己成为一项新的产业和城市经济增长点。 
灯贸会成为一个融文化、科技、旅游为一体的大节庆, 一个团结合作、开放发展、对外 宣传的大窗口，一个客商云集、招商引资的大市场。

人民造就了灯会, 灯会造福于人民。伴随着新世纪的到来, 自贡灯会必将以新的胜景奇 观、异彩神韵出现在海内外, 绽放出更加绚丽夺目的光辉。”

The translation version:

“...

The festival has become a big holiday of integration of culture, science and technology, tourism, a big platform of lantern culture industry development, a big window of unity and cooperation, opening and development, and publicity of Zigong and a big market full of traders and investment.

In Zigong, lantern fabrication, lantern show and Lantern Festival trade fair have become a new industry and urban economic growth.

People create the Lantern Festival and it benefits the people."

In the source text, “在自贡, 制灯、展灯、举办灯会经贸交易会己成为一项新的产业和城 市经济增长点。”, which is showing a phenomenon in Zigong,is written after “进入九十年代 以来, 自贡灯会作为中华民族的文化使者, 更大步地走出国门, .......将中国灯文化的奇 光异彩传播到海外各地。......自贡灯会向着经贸型、集约化、国际化方向发展, 取得了 良好的社会效益和经济效益。”, which introduces the international development of Zigong Lantern Festival; However, “灯贸会成为一个融文化、科技、旅游为一体的大节庆，一个 团结合作、开放发展、对外宣传的大窗口，一个客商云集、招商引资的大市场。”, whichis still talking about the international status of Zigong Lantern Festival, is written before “人民 造就了灯会, 灯会造福于人民。伴随着新世纪的到来, 自贡灯会必将以新的胜景奇观、 异彩神韵出现在海内外, 绽放出更加绪丽夺目的光辉。”, which indicates Zigong people benefit a lot from Zigong Lantern Festival. So it is not so coherent with the context. A translation should be natural and easy to follow, so the translator adjusted the sequence of sentences when translating and the translation became more coherent and accessible to the readers.

\subsubsection{The Supplement of Information}

According to Newmark, the translator has the right to supple information to assure that target readers can gain enough information beyond the language itself. Here are some cases where the translator applied this principle perfectly.

\section{Case $_{1}$ :}

"In 1964, Zigong people's government hosted the first lantern festival after the founding of new China and the cultural and economic activities were combined dynamically. On the spring festival of 1987, Zigong Communist Party Committee and People's government kept up with the trend of the history of reform and opening-up, with the joint efforts of the people 
in the city, held the first Zigong International Dinosaur Festival and Economy and Trade Fair."

This paragraph is not in the source text, which introduces the first Lantern Festival after the founding of new China. It is a significant stage for the development of Zigong Lantern Festival, and shows both the efforts of people and the concerns from government. For target readers, the supplement of this information is necessary because with it, people have a complete comprehension of the developing stages.

Some supplement is made to affect target readers psychologically and call them to feel and act.

\section{Case $_{2}$ :}

"Due to its great impact, Zigong lantern festival is called "The First Lantern Show in the World". Zigong Lantern Festival is one of the two largest folk activities in China determined by the State Tourism Bureau, and the top one of the 40 folk activities. It is the "outstanding cultural products and services for export" awarded by the State Culture Ministry. In 1986, Zigong lantern festival was appointed as the State-level non-material cultural heritage by the State Council. In 2004, Zigong lantern development park of China was appointed as the "national cultural industry demonstration base" by the State Culture Ministry. It has been awarded many times the best international exchange prize, carrying forward traditional festival prize, "golden dolphin" festival prize and one of the top ten famous festivals in China. The landscape lighting in the lantern city of South China is awarded the "green lighting demonstration project" by the State Ministry of Construction. The State leaders Deng Xiaoping, Jiang Zemin and $\mathrm{Hu}$ Jintao have shown their special concern, support and affirmation to Zigong lantern festival."

Text of $\mathrm{Case}_{2}$, which enumerates numerous prizes and reputations awarded to Zigong Lantern Festival, is added by the translator because firstly, these facts are essential components of introduction of Zigong Lantern Festival; Secondly, people can gain more information from the list, they may realize the incomparable lantern quality and faithworthy prestige; Then they will be inclined to make up their minds to visit the lantern festival or to seek cooperation with Zigong Lantern Festival.

\subsection{Suggestions for the Translation Text}

\subsubsection{Redundancy to Be Deleted}

Viewing from Newmark, a translation should be concise and the translator is responsible to eliminate repetition and tautology. During the process of translating Zigong Lantern Festival introduction, the translator may not deal it well.

\section{Sentence : $^{2}$}

"The approach has got the concern, support and affirmation of CP and State leaders Deng Xiaoping and Jiang Zemin, General Secretary of CP." 


\section{Sentence $_{2}$ :}

"The State leaders Deng Xiaoping, Jiang Zemin and Hu Jintao have shown their special concern, support and affirmation to Zigong lantern festival."

Sentence $_{1}$ can be found in the original text, following the introduction of the tenet and orientation. While Sentence ${ }_{2}$ is added when suppling the information of the prizes and reputations awarded to Zigong Lantern Festival. Both these two sentences use the same structure and words, so it may be some kind of wordy. Here Sentence ${ }_{2}$ is suggested to be cancelled. To sum up, the translation has to contain the right amount of information, which can appeal to the readers. Too much or too little information will cause difficulty for the readers.

\subsubsection{Revision to Be Made for the Sake of Communicative Effect}

Translation is for communication at some level. According to Newmark, communicative translation attempts to produce on its readers an effect as close as possible to what is obtained on the readers of the original (Newmark, 2001: 39). Through the analysis of the source text and translation, the author thinks that some revision should be made for a better translation.

The source text:

“......坚持‘ 人民灯会人民办”的方针； …...”

The translation:

“...The orientation of 'people's lantern festival made by the people' was initiated."

In the source text, the connotation of “人民灯会人民办” tends to be “人民的灯会（应）由人 民办”, which is the orientation that should be insisted. While in the translation, the translator put it as "people's lantern festival made by the people", using a past participle phrase "made by the people" as postpositive attributive to modify and complete the qualified word “festival”. On one hand, if we make a retroversion, it turned out to be “人民办的人民的灯 会”, which is far away from the original meaning and can not correspond to the word "orientation", which suggests a principle or policy of doing things. On the other hand, the target readers, who first see the word "orientation", expect to be informed the specific content of an orientation. However, they finally receive a simply qualified word "festival". Thus, it can be said that the translation failed to have the communication effect on readers.

Based on the analysis above, the author suggest the translation of “人民灯会人民办” to be a sentence, i.e. "people's lantern festival should be made by the people", instead of the phrase "people's lantern festival made by the people"

\section{Conclusion}

In general, the choosing of translation strategy should follow the rule of the communicative intention of discourse. Similarly, the standard of assessment for the quality of the translation is to see whether the translation text realize the transmission of primary function of the source text under the translation communicative circumstance. Newmark's communicative 
translation theory provides a fresh perspective for the translation of Zigong Lantern Festival. Communicative translation focuses on information transmission based on the language, culture and pragmatic ways of the target text rather than a faithful reproduction of the original text. It regards the original form of the text just as factors that should be considered and the translator has more freedom to interpret the original text in communicative translation. No matter how to deal with the source text, one should bear in mind that translation is for communication. As long as the translation can achieve the purpose of providing enough information and carrying forward Chinese culture, the translator does not have to rigidly stick to some kind of translation method and the original form, but boldly translate instead.

\section{Acknowledgements}

The research is financed by the University Students Innovation Fund (No.201310622045).

\section{References}

Hu, Z. (2011). A Study on C-E Translation of Tourism Texts from the Perspective of Peter Newmark's Translation Theory. Guangxi Teachers Education University.

Newmark, P. (2001). Approaches to Translation. Shanghai Foreign Language Education Press.

Official webpage of Zigong Lantern Festival. Retrieved December 1, 2013, from http://www.zgdenghui.cn/index.asp

Wang, H. (2010). Logic Analysis and Translation. Journal of Chifeng University, 5, 141-142.

Yan, D. (1999). A conception of Logic Translatology. Foreign Language Education, 2, 42-48.

Ye, M. (2013). An Analysis of the Translation of Kennedy's First Inaugural Address from the Perspective of Newmark's Translation Theory. Journal of Language and Literature Studies, 5, $72-74$.

\section{Notes}

Note 1: In China, there are many lantern shows, such as Chengdu Lantern Show, Qianjiang Lantern Show, Nanjing Lantern Show and Yangzhou Lantern Show. Even in the famous Nanjing Qinhuai lantern show, the" hometown of Chinese folk lantern art culture", Zigong lanterns take up $50 \%$ of it.

Note 2: see the introduction of Zigong city on webpage: http://2008.sohu.com/20080519/n256949592.shtml(May 19, 2008)

\section{Copyright Disclaimer}

Copyright reserved by the author(s).

This article is an open-access article distributed under the terms and conditions of the Creative Commons Attribution license (http://creativecommons.org/licenses/by/3.0/). 